\title{
Radial nerve palsy due to supracondylar open fracture in a child
}

\author{
Naoki Yoshida, Yoshihiko Tsuchida
}

Department of Orthopedic Trauma Surgery, Shonankamakura General Hospital, Kanagawa, Japan

\section{Correspondence to} Dr Naoki Yoshida,

n_yoshida@shonankamakura. or.jp

Accepted 2 October 2017

\section{CrossMark}

\section{To cite: Yoshida $\mathrm{N}$} Tsuchida Y. BMJ Case Rep Published Online First: [please include Day Month Year]. doi:10.1136/bcr-2017 222303

\section{DESCRIPTION}

A 9-year-old boy presented to the emergency department with severe left elbow pain after a fall from a skateboard. On physical examination, an open injury in his left elbow that exposed the humeral lateral epicondyle was observed (Gustilo grade; figure 1A). The radial pulse was well palpated, but the neurological diagnosis was impossible because of severe pain.

A radiograph revealed a supracondylar humeral fracture in which the distal fragment was remarkably displaced (Figure 1B, C). After adequate preanaesthetic clearance, the patient was planned for surgery. On further exploration, the radial nerve was tenting strongly by the displaced bone fragment (figure 1D). Hence, the radial nerve was carefully released, and its continuity was maintained. In addition, the supracondylar humeral fracture was stabilised with Kirschner wires. On postoperative day 1 , because a left wrist drop associated with hypoesthesia was observed, we diagnosed radial nerve palsy (figure $2 \mathrm{~A}, \mathrm{~B}$ ). The radial nerve was found almost intact after releasing; therefore, we decided to carefully follow-up for palsy. Five months later, palsy had completely recovered.

Reportedly, supracondylar humeral fractures are one of the most common fractures around the elbow joint in the paediatric age group. Paediatric supracondylar humeral fractures are rarely associated with a radial nerve injury. Generally, radial nerve palsy results from traction injury, contusion, tenting and entrapment at the fracture site. ${ }^{2}$

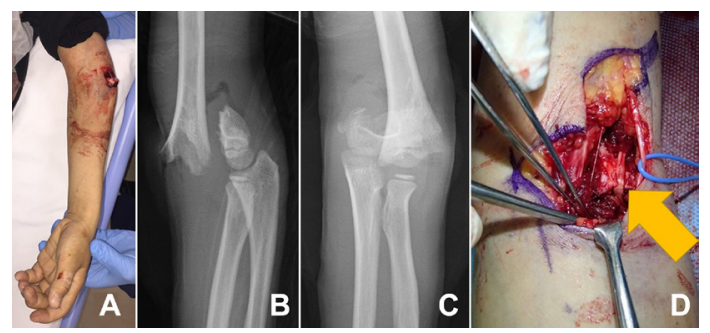

Figure 1 (A) The clinical photograph depicts the open injury on the left elbow. (B) The lateral radiograph shows supracondylar fracture that was remarkably displaced. (C) The anteroposterior radiograph shows supracondylar fracture that was remarkably displaced. (D) The clinical photograph depicts the tenting radial nerve.
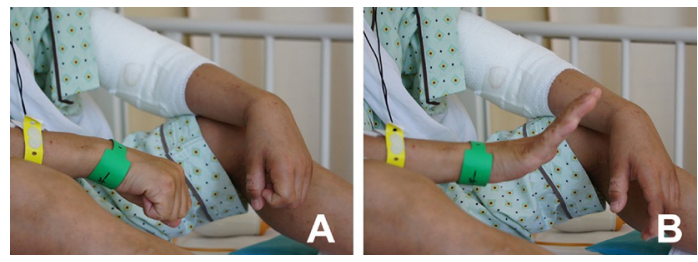

Figure 2 (A) The clinical photograph depicts the limb position with instructed palm flexion. (B) The clinical photograph depicts the limb position with instructed dorsiflexion. Because he cannot dorsiflex his left hand, this indicates radial nerve palsy.

The management of radial nerve palsy is controversial, as some will advocate a conservative approach because majority will resolve spontaneously. ${ }^{1}$ Others will advocate open reduction and exploration to prevent entrapment and iatrogenic laceration. ${ }^{3}$ Especially, in the 'pink, pulseless hand', a concurrent nerve palsy prompts early exploration as it is strongly predictive of nerve and vessel entrapment. Our patient needed open reduction to prevent entrapment and iatrogenic laceration because the radial nerve was tenting strongly by the remarkably displaced bone fragment. When managed appropriately, nerve recovery and clinical outcomes for this paediatric population are extremely favourable. ${ }^{2}$

It is important to examine and treat paediatric supracondylar fracture with a radial nerve injury in mind.

\section{Learning points}

Paediatric supracondylar humeral fractures are common and rarely associated with a radial nerve injury.

- When managed appropriately, nerve recovery and clinical outcomes for this paediatric population are extremely favourable.

- It is important to examine and treat paediatric supracondylar fracture with a radial nerve injury in mind.

Contributors The patient's care was overseen by NY and YT. YT provided assistance with the drafting of the manuscript. All authors approved the manuscript prior to submission.

Competing interests None declared.

Patient consent Guardian consent obtained.

Provenance and peer review Not commissioned; externally peer reviewed.

(c) BMJ Publishing Group Ltd (unless otherwise stated in the text of the article) 2017. All rights reserved. No commercial use is permitted unless otherwise expressly granted. 


\section{REFERENCES}

1 Abu-Jayyab Z, Abu-Zidan F, Marlovits S. Fracture dislocation of the lateral condyle and medial epicondyle of the humerus associated with complete radial nerve transection. J Pak Med Assoc 2011;61:920-1.
2 Kwok IH, Silk ZM, Quick TJ, et al. Nerve injuries associated with supracondylar fractures of the humerus in children: our experience in a specialist peripheral nerve injury unit. Bone Joint J 2016;98-B:851-6.

3 Reichert P, Wnukiewicz W, Witkowski J, et al. Causes of secondary radial nerve palsy and results of treatment. Med Sci Monit 2016;22:554-62.

Copyright 2017 BMJ Publishing Group. All rights reserved. For permission to reuse any of this content visit http://group.bmj.com/group/rights-licensing/permissions.

BMJ Case Report Fellows may re-use this article for personal use and teaching without any further permission.

Become a Fellow of BMJ Case Reports today and you can:

- Submit as many cases as you like

- Enjoy fast sympathetic peer review and rapid publication of accepted articles

- Access all the published articles

Re-use any of the published material for personal use and teaching without further permission

For information on Institutional Fellowships contact consortiasales@bmjgroup.com

Visit casereports.bmj.com for more articles like this and to become a Fellow 